\title{
Cold exposure restores the decrease in leptin receptors (OB-Rb) caused by neonatal leptin treatment in 30-day-old rats
}

\author{
S C P Dutra, E G Moura, A L Rodrigues, P C Lisboa, I Bonomo, F P Toste and M C F Passos ${ }^{1}$ \\ Department of Physiological Sciences, State University of Rio de Janeiro, 'Department of Applied Nutrition, Nutrition Institute, State University of Rio de Janeiro, \\ 20550-030 Rio de Janeiro, RJ, Brazil \\ (Correspondence should be addressed to M C F Passos who is now at Departamento de Ciências Fisiológicas- $5^{\circ}$ andar, Instituto de Biologia, Universidade do \\ Estado do Rio de Janeiro, Avenue 28 de setembro, 87, Rio de Janeiro, RJ 20550-030, Brazil; Email: magna.cottini@pq.cnpq.br)
}

\begin{abstract}
We had previously shown that neonatal leptin treatment programs thyroid function in adulthood. As both thyroid hormones $(\mathrm{TH})$ and leptin increased thermogenesis, it was interesting to evaluate the effect of cold exposure on the thyroid function of neonate rats treated with leptin. Pups were divided into two groups: Lep, injected with leptin $(8 \mu \mathrm{g} / 100 \mathrm{~g} / \mathrm{BW}$, s.c.) for the first 10 days of lactation and control (C), injected with saline. When they were 30 days old, the groups were subdivided into two subgroups: LepC and CC, which were exposed to $8{ }^{\circ} \mathrm{C}$ for $12 \mathrm{~h}$ and compared with $\mathrm{C}$ and Lep groups, maintained at $25 \pm 1{ }^{\circ} \mathrm{C}$. Serum leptin, $\mathrm{TH}$, and TSH were measured by RIA. Type I liver deiodinase (D1) and mitochondrial $\alpha$-glycerol-3-phosphate dehydrogenase (mGPD) activities were assayed by the release of ${ }^{125} \mathrm{I}$ from ${ }^{125}$ I-reverse and colorimetric method respectively. Leptin receptor $(\mathrm{OB}-\mathrm{Rb})$ was evaluated by western blot.
\end{abstract}

Lep group had hyperleptinemia $(+22 \%)$ and lower free tri-iodothyronine $\left(\mathrm{FT}_{3} ;-33 \%\right)$. Cold exposure increased $\mathrm{TH}$ both in LepC and CC groups compared with respective controls free thyroxine $\left(\mathrm{FT}_{4}:+63\right.$ and $+39 \% ; \mathrm{FT}_{3}:+75$ and $+40 \%)$. Liver D1 activity was lower in Lep $(-22 \%)$ and increased with cold exposure (LepC $+51 \%$ and $\mathrm{CC}+22 \%)$. The mGPD activity was lower in Lep $(-34 \%)$ and increased (fourfold) when this group is cold exposed. Hypothalamic and thyroidal $\mathrm{OB}-\mathrm{Rb}$ receptors were lower in Lep group $(-47$ and $-36 \%$ respectively) and they were restored to normal levels after cold exposure. Leptin-programmed rats had higher TH response after cold exposure. OB-Rb had a fast response to cold exposure normalizing the lower levels observed in the leptin-programmed animals and may contribute to the higher $\mathrm{TH}$ cold responses.

Journal of Endocrinology (2007) 195, 351-358

\section{Introduction}

Experimental studies have shown that environmental changes, such as nutritional, endocrine disruptors, and other stressful events, occurring in a critical period early in life, permanently program the structure and physiology of the body's tissues and systems. Those environmental changes act to imprint hormonal, neurological, or metabolic changes that are responsible for the programming effects (Armitage et al. 2004, Moura \& Passos 2005).

Malnutrition during lactation changes the pup's leptin serum levels (Teixeira et al. 2002) and programs body weight (Passos et al. 2000) and thyroid function (Passos et al. 2002). Therefore, we hypothesized that leptin could be an imprinting factor for malnutrition programming. Further, we demonstrated in rats that leptin injection during the first half of lactation is associated with hyperleptinemia and hypothyroidism in 30-day-old animals (Toste et al. 2006a). Those rats were programed for hyperleptinemia, higher serum thyroid hormones $(\mathrm{TH})$, and lower serum thyrotrophin (TSH) levels when they were 150 days old. Thus, we conclude that a 30-day period is critical for the establishment of the hormonal imprinting for this programming. Besides, we showed that these animals had central leptin resistance and lower hypothalamic OB-Rb expression in adulthood (Toste et al. 2006b).

Leptin has a well-known stimulatory role upon thyroid function, increasing thyrotrophin-releasing hormone (TRH) and TSH (Legradi et al. 1997, Nillni et al. 2000, Ortiga-Carvalho et al. 2002), or directly upon its receptors on the thyroid, increasing TH secretion (Nowak et al. 2002). Leptin receptors are present in the hypothalamus (Tartaglia 1997, Toste et al. 2006b), pituitary (Vicente et al. 2004) and thyroid glands (Nowak et al. 2002). The thyroid OB-Rb expression has been shown until now only by Nowak et al. (2002) in normally fed female rats.

Both TH and leptin have profound stimulatory effects on thermogenesis (Bianco \& Silva 1987, Carvalho et al. 1991, Silva 1995, Gong et al. 1997, Hausberg et al. 2002, Ukropec et al. 2006). Cold exposure is associated with rapid activation of the hypothalamus-pituitary-thyroid axis (Hefco et al. 1975, Joseph-Bravo et al. 1998) and peripheral conversion of 
thyroxine $\left(\mathrm{T}_{4}\right)$ into tri-iodothyronine $\left(\mathrm{T}_{3}\right.$; Pazos-Moura et al. 1991, Reed et al. 1994, Lisboa et al. 2003). In contrast, cold exposure reduces the circulating leptin levels (Hardie et al. 1996, Bing et al. 1998) and the expression of the ob gene in brown adipose tissue (BAT) and white adipose tissue (WAT) of rodents (Trayhurn et al. 1995, Puerta et al. 2002). These findings may be caused by the cold-induced increase in sympathetic activity in these tissues (Trayhurn et al. 1995).

As TH and leptin serum concentrations and hypothalamic OB-Rb expression have important changes when the animals were programmed by neonatal leptin treatment, in the present study, we evaluated the effect of cold exposure on the thyroid function as well as the expression of the OB-Rb of leptinprogrammed 30-day-old animals.

\section{Materials and Methods}

Animals and experimental design

The use of the animals was in agreement with the Animal Care and Use Committee of the Biology Institute of the State University of Rio de Janeiro, which based its analysis on the principles described in the Guide for the Care and Use of Laboratory Animals (Bayne 1996).

Wistar rats were kept in a room with controlled temperature $\left(25 \pm 1^{\circ} \mathrm{C}\right)$ and with artificial dark-light cycles (lights on from 0700 to $1900 \mathrm{~h}$ ). Virgin female rats aged 3 months old were caged with one male rat at a proportion of 3:1. After mating, each female was placed in an individual cage with free access to water and food until the pups' birth.

Within $24 \mathrm{~h}$ of birth, excess number of pups were removed, so that only six male pups were kept per dam. Such a procedure has shown maximization in the lactation performance (Fishbeck \& Rasmussen 1987). The study was performed using 16 male pups, from four different dams, in each experimental group. Pups were randomly assigned to two groups: the control group (C) was given an s.c. injection of saline $(\mathrm{NaCl} 0 \cdot 9 \%)$ during the first 10 days of lactation, and the leptin group (Lep) was treated with recombinant mouse leptin (provided by PeproTech Inc., London, England) in a daily dose of $8 \mu \mathrm{g} / 100 \mathrm{~g}$ body weight during the first 10 days of lactation. The recombinant mouse leptin was dissolved in saline and all the injections were given at $1600 \mathrm{~h}$.

The pups were weaned at 21 days old. After weaning, two animals of each dam were randomly chosen and placed together in the cage with free access to water and food until day 30 of life. At 30 days old, the pups treated with leptin or saline were subdivided into control cold (CC, eight animals) and leptin cold (LepC, eight animals) groups, which were kept in individual cages and exposed to $8{ }^{\circ} \mathrm{C}$ for $12 \mathrm{~h}$ and compared with $\mathrm{C}$ (eight animals) and Lep (eight animals) groups maintained at $25 \pm 1{ }^{\circ} \mathrm{C}$ for the same period. Immediately after $12 \mathrm{~h}$ of cold exposure, the animals were killed in the cold room, and the other animals (group $\mathrm{C}$ and Lep) in the laboratory $\left(25 \pm 1^{\circ} \mathrm{C}\right)$, simultaneously, with a dose of anesthetic (40 mg/ kg body weight, i.p.; Thiopental, Cristália, Brazil) and blood was obtained by cardiac puncture. Blood samples were centrifuged $\left(5600 \mathrm{~g}, 4{ }^{\circ} \mathrm{C}, 20 \mathrm{~min}\right)$ to obtain serum which was kept at $-20{ }^{\circ} \mathrm{C}$ until the assay. Hypothalamus, thyroid gland, and liver were excised and immediately frozen in liquid nitrogen. Tissue samples were stored at $-70{ }^{\circ} \mathrm{C}$ until further analysis.

\section{Body weight, food intake, and rectal temperature}

Body weight was monitored daily during lactation and every 4 days after weaning until they were 30 days old, when they were killed. The food intake was measured every 4 days after weaning until 30 days old. At 30 days old, immediately after $12 \mathrm{~h}$ of cold exposure, the rectal temperature, body weight, and food intake were measured. Rectal temperature was measured using a digital thermometer inserted $\sim 1.5 \mathrm{~cm}$ into the anus.

\section{Serum hormone concentrations}

Leptin was measured by RIA (Linco Research Inc., St. Charles, MO, USA). This kit measures both rat and mouse leptin with an assay sensitivity of $0.5 \mathrm{ng} / \mathrm{ml}$ and a range of detection from 0.5 to $50 \mathrm{ng} / \mathrm{ml}$. The inter- and intra-assay variations were $7 \cdot 3$ and $6.9 \%$ respectively.

Free serum $\mathrm{T}_{3}\left(\mathrm{FT}_{3}\right)$ and free serum $\mathrm{T}_{4}\left(\mathrm{FT}_{4}\right)$ were measured by RIA, using commercial kits (Coat-A-Coat, DPC, Los Angeles, CA, USA). The inter- and intra-assay variations were $5 \cdot 4$ and $3 \cdot 6 \%$ for $\mathrm{FT}_{3}$ and $6 \cdot 3$ and $4 \cdot 4 \%$ for $\mathrm{FT}_{4}$ respectively.

Serum TSH was determined by specific RIA, using a kit for rat TSH supplied by the NIDDKD (Bethesda, MD, USA) and data were expressed in terms of the RP provided (RP-3). The intra-assay variation was $0 \cdot 6 \%$ and all measurements were performed in a unique assay.

\section{Mitochondrial $\alpha$-glycerol-3-phosphate dehydrogenase (mGPD) activity determination}

We followed the procedure described previously with slight modifications (Lee \& Lardy 1965, Bernal et al. 1978, Recupero et al. 1983). To isolate the mitochondrial fraction, liver $(250 \mathrm{mg})$ was homogenized in $5 \mathrm{ml}$ sucrose magnesium solution $\left(0.32 \mathrm{M}\right.$ sucrose, $\left.1 \mathrm{mM} \mathrm{MgCl}_{2}\right)$ with Ultra Turrax and then centrifuged at $1000 \mathrm{~g}$ for $10 \mathrm{~min}$ at $4{ }^{\circ} \mathrm{C}$ to separate the crude nuclear pellet which was discarded. The supernatant was centrifuged at $8500 \mathrm{~g}$ for $10 \mathrm{~min}$ at $4{ }^{\circ} \mathrm{C}$ and the pellet was washed with $0 \cdot 125 \mathrm{M}$ potassium phosphate buffer (KBP; $\mathrm{pH} \mathrm{7.5)} \mathrm{in} \mathrm{a} \mathrm{vortex} \mathrm{and} \mathrm{followed} \mathrm{by} \mathrm{another}$ centrifugation under the same conditions. The pellet containing the mitochondrial fraction was resuspended in $1 \mathrm{ml} \mathrm{KBP}$.

In order to assay, mitochondrial suspension $(100 \mu \mathrm{l})$ was mixed with $50 \mu \mathrm{l}$ of $0 \cdot 1 \mathrm{MDL}-\boldsymbol{\alpha}$-glycerophosphate diluted in $\mathrm{KCN} / \mathrm{KPB}(0 \cdot 32 \mathrm{mg} / \mathrm{ml})$. Blank tubes contained only $\mathrm{KCN}$ 
and $\mathrm{KPB}$. After $10 \mathrm{~min}$ at $30^{\circ} \mathrm{C}$, all tubes were transferred to a cold water bath $\left(4^{\circ} \mathrm{C}\right)$ and $100 \mu$ solution of $7.9 \mathrm{mM}$ INT $-0.12 \mathrm{mM}$ PMS was added. After $15 \mathrm{~min}$ at room temperature in the dark, the reaction was stopped by the addition of $50 \mu \mathrm{l}$ TCA $10 \%$ and $1 \mathrm{ml}$ absolute ethanol and tubes were centrifuged at $1000 \boldsymbol{g}$ for $5 \mathrm{~min}$. Supernatant was analyzed at $500 \mathrm{~nm}$ and the values were expressed as absorbance $(\mathrm{OD}) / \mathrm{mg}$ of mitochondrial protein. Protein was measured using the method described by Bradford (1976).

\section{Hepatic deiodinase type I (D1) activity determination}

Liver tissue $(250 \mathrm{mg})$ was homogenized in $50 \mathrm{mM}$ Tris- $\mathrm{HCl}$ buffer (pH 6.8) and centrifuged at $1500 \mathrm{~g}$ at $4{ }^{\circ} \mathrm{C}$ for $20 \mathrm{~min}$. The supernatants were stored at $-70{ }^{\circ} \mathrm{C}$ until assayed. Assay for hepatic D1 activity was performed by the release of ${ }^{125} \mathrm{I}$ from the ${ }^{125} \mathrm{I}$-labeled reverse $\mathrm{T}_{3}\left(\mathrm{rT}_{3}\right)$, with minimal modifications as previously described (Pazos-Moura et al. 1991, Dutra et al. 2003, Lisboa et al. 2003). Hepatic homogenates (35-270 $\mathrm{g}$ protein) were assayed for D1 activity in phosphate buffer containing $1 \mathrm{mM}$ EDTA, $\mathrm{pH}$ $6 \cdot 9$, in the presence of $1.5 \mu \mathrm{M} \mathrm{rT}_{3}$ and $10 \mathrm{mM}$ dithiothreitol. Equal volumes of the ${ }^{125} \mathrm{I}_{-} \mathrm{rT}_{3}(1.07 \mathrm{mCi} / \mu \mathrm{g}$; Dupont-New England Nuclear, Boston, MA, USA), which was previously purified by paper electrophoresis, were added to each assay tube. They were incubated in shaking water bath at $37^{\circ} \mathrm{C}$ and then stopped $30 \mathrm{~min}$ later by the addition of a mixture of $8 \%$ BSA and $10 \mathrm{mM}$ PTU, followed by cold $20 \%$ trichloroacetic acid. The samples were then centrifuged $\left(5600 \mathrm{~g}, 4^{\circ} \mathrm{C}\right.$, $5 \mathrm{~min}$ ), and $200 \mu \mathrm{l}$ supernatants were applied to Dowex 50 W-X2 columns (100-200 mesh hydrogen from Bio-Rad). Free ${ }^{125}$ I eluted from the column with $10 \%$ acetic acid was measured in a gamma counter. The specific enzyme activity was expressed by protein nanomoles of $\mathrm{rT}_{3}$ deiodinated/h per mg. Protein was measured by the method described by Bradford (1976).

\section{Western blot of the hypothalamic and thyroidal leptin receptor}

Hypothalamus or thyroid was homogenized on ice-cold lysis buffer $\mathrm{pH} 6.4$ (50 mM HEPES, $1 \mathrm{mM} \mathrm{MgCl}_{2}, 10 \mathrm{mM}$ EDTA, Triton X-100 1\%, $1 \mathrm{mg} / \mathrm{ml}$ aprotinin, $1 \mathrm{mg} / \mathrm{ml}$ leupeptin, $1 \mathrm{mg} / \mathrm{ml} \mathrm{SBTI})$. The protein concentration was determined by the method of Bradford (1976).

The proteins $(60 \mu \mathrm{g})$ were separated by SDS-PAGE (10\%) and transferred to a nitrocellulose membrane (Hybond ECL; Amersham Pharmacia Biotech). The membrane was blocked for $1 \mathrm{~h}$ by $5 \%$ nonfat milk in TBS-T buffer $(20 \mathrm{mM}$ Tris, $\mathrm{pH} 7 \cdot 5$, $0 \cdot 5 \mathrm{M} \mathrm{NaCl}, 0 \cdot 1 \%$ Tween 20 ) followed by overnight incubation with primary antibody OB-Rb (m-18, goat polyclonal, Sc-1834, antihuman leptin receptor; Santa Cruz Biotechnology, Santa Cruz, CA, USA) in TBS-T (1:500), washed thrice with TBS-T, and incubated with secondary antibody (biotinconjugated goat IgG, 1:1000) for $1 \mathrm{~h}$. After the membrane had been washed thrice with TBS-T, it was incubated with streptavidin (avidin-conjugated peroxidase) for $1 \mathrm{~h}$. Antibody binding was visualized using 3,3'-diaminobenzidine tetrahydrochloride (10 $\mathrm{mg}$ in $15 \mathrm{ml}$ Tris buffer, $0 \cdot 1 \mathrm{M}, \mathrm{pH} 7 \cdot 4$ ). The results were normalized with actin. Densitometry analyses of the immunoreactive bands were determined by Proplus image software (Infaimon, Barcelona, Spain).

\section{Statistical analysis}

The data are reported as mean \pm s.e.m. Two-way ANOVA and Student's $t$-test were used to analyze body weight and food intake in response to the leptin treatment. The other experimental data were analyzed by the one-way ANOVA followed by the Newman-Keuls test. The level of significance was set at $P<0 \cdot 05$.

\section{Results}

Body weight, food intake, and rectal temperature

Body weight from birth to 30 days old is shown in Fig. 1. During that time, Lep group had a lower body weight than that of $\mathrm{C}$ group, from day 3 to 21 of leptin injection (approximately $-5 \%, P<0 \cdot 04)$. After day 21 , these animals regained body weight, and reached the same weight of $\mathrm{C}$ group within 30 days.

Table 1 shows the effect of $12-\mathrm{h}$ cold exposure $\left(8^{\circ} \mathrm{C}\right)$ on the body weight, food intake, and body temperature in 30-day-old rats. The body weight and food intake of the Lep
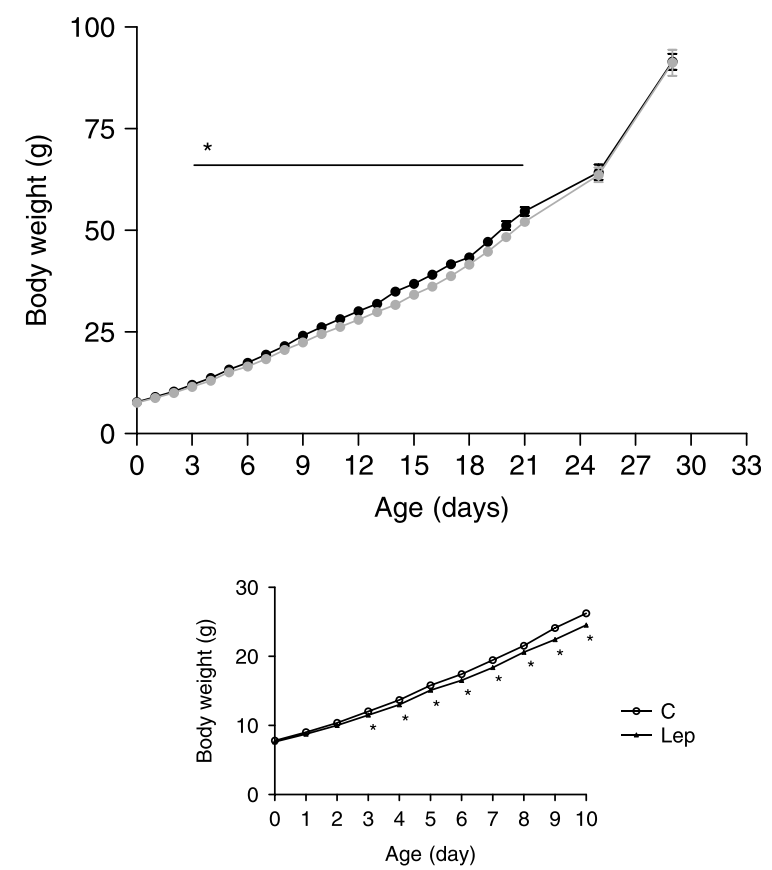

Figure 1 Body weight from birth to 30 days old of animals treated with saline (black line) or with leptin (gray line) on the first 10 days of lactation. Values are given as the mean \pm S.E.M. of 16 animals per group. ${ }^{*} P<0 \cdot 05$. 
Table 1 Body weight, food intake, and body temperature of controls and cold-exposed rats when 30 days old programed with leptin on neonatal period. Values are means \pm S.E.M. of eight animals per group

\begin{tabular}{|c|c|c|c|c|}
\hline & C & $\mathrm{CC}$ & Lep & LepC \\
\hline Body weight, g & $93 \cdot 22 \pm 2 \cdot 216$ & $85 \cdot 2 \pm 2 \cdot 682^{*}$ & $92 \cdot 17 \pm 1 \cdot 537$ & $91 \cdot 06 \pm 1 \cdot 471$ \\
\hline Food intake, g & $10 \cdot 06 \pm 0 \cdot 2371$ & $7 \cdot 864 \pm 0 \cdot 3897^{*}$ & $9 \cdot 375 \pm 0 \cdot 2814$ & $7 \cdot 795 \pm 0 \cdot 3421^{\dagger}$ \\
\hline Body temperature, ${ }^{\circ} \mathrm{C}$ & $37 \cdot 3 \pm 0 \cdot 1932$ & $37 \cdot 25 \pm 0 \cdot 4717$ & $37 \cdot 6 \pm 0 \cdot 1182$ & $37 \cdot 68 \pm 01401$ \\
\hline
\end{tabular}

C, Control group; CC, control group cold exposed; Lep, leptin group; LepC, leptin group cold exposed. *Significant differences between CC group versus C; ${ }^{\dagger}$ between LepC group versus Lep. The level of significance was set at $P<0 \cdot 05$.

group kept at $25 \pm 1{ }^{\circ} \mathrm{C}$ did not change. Cold exposure led to loss of body weight $(-8 \cdot 6 \% ; P<0 \cdot 05)$ and lower food intake $(-21 \cdot 8 \% ; P<0 \cdot 001)$ in CC group compared with the $\mathrm{C}$ group, whereas in the LepC group, it did not affect the body weight but led to lower food intake $(-16 \cdot 8 \% ; P<0 \cdot 01)$ compared with the Lep group. Cold exposure did not affect the body temperature in both $\mathrm{CC}$ and LepC groups compared with the respective controls.

\section{Serum hormone concentrations}

Serum leptin concentrations are shown in Fig. 2. Lep group had higher serum leptin concentrations than the $\mathrm{C}$ group $(+$ $22 \%, P<0 \cdot 05)$. Cold exposure led to the decrease of serum leptin only in LepC group $(-20 \%, P<0 \cdot 05)$ compared with the Lep group, restoring those concentrations to the control values.

Figure 3 (A and B) shows the effect of cold exposure on the $\mathrm{TH}$ serum concentrations of rats treated with leptin on the lactation. The Lep group had a lower serum $\mathrm{FT}_{3}(-33 \%$, $P<0 \cdot 05)$ and normal $\mathrm{FT}_{4}$ compared with the control. Cold exposure increases $\mathrm{TH}$ both at LepC $\left(\mathrm{FT}_{4}:+63 \%, P<0 \cdot 01\right.$

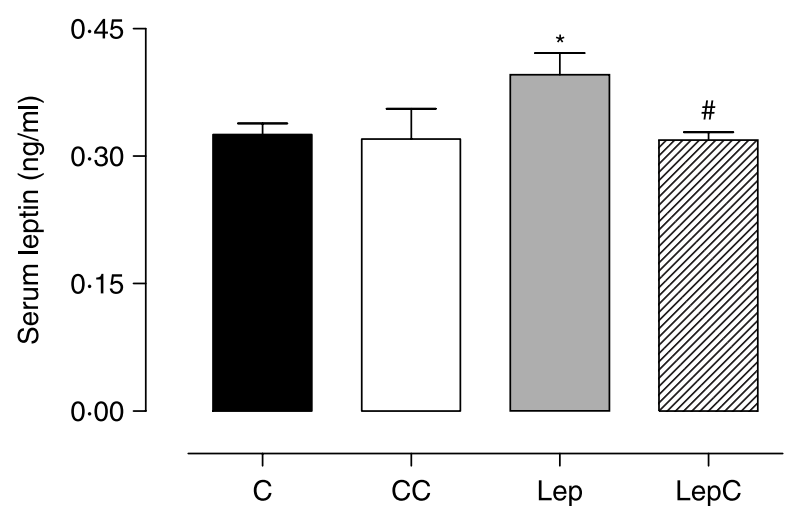

Figure 2 Leptin serum concentrations of animals treated with saline and kept at $25{ }^{\circ} \mathrm{C}$ when 30 days old (C group, black bar), treated with saline and exposed to $8{ }^{\circ} \mathrm{C}$ for $12 \mathrm{~h}$ (CC group, white bar), treated with leptin on the first 10 days of lactation and kept at $25^{\circ} \mathrm{C}$ when 30 days old (Lep group, gray bar), and treated with leptin on the first 10 days of lactation and exposed to $8{ }^{\circ} \mathrm{C}$ for $12 \mathrm{~h}$ when 30 days old (LepC group, hatched bars). Values are given as the mean \pm S.E.M. of eight animals per group. $\left(^{*}\right)$ Significant differences between Lep and CC groups and C, (\#) between LepC and Lep. The level of significance is set at $P<0 \cdot 05$. and $\left.\mathrm{FT}_{3}:+75 \%, P<0 \cdot 01\right)$ and $\mathrm{CC}\left(\mathrm{FT}_{4}:+39 \%, P<0 \cdot 05\right.$ and $\left.\mathrm{FT}_{3}:+40 \%, \quad P<0 \cdot 05\right)$ groups compared with respective controls. Serum TSH had a response compatible to a normal feedback; however, those changes were not statistically significant (Fig. 3C).

\section{D1 and $m$ GPD activity}

Liver D1 activity (Fig. 4A) was lower in Lep group ( $-22 \%$, $P<0 \cdot 05)$ compared with the $\mathrm{C}$ group and increased in both cold-exposed groups (LepC= $+51 \%, \quad P<0 \cdot 001$ and $\mathrm{CC}=+22 \%, P<0 \cdot 05$, compared with the Lep and $\mathrm{C}$ groups respectively) restoring to normal values the lower activity observed in Lep C. Liver mGPD activity was lower in the Lep group $(-34 \%, P<0 \cdot 05)$ compared with the $\mathrm{C}$ group. Cold exposure increased activity of this enzyme only in the LepC group (fourfold, $P<0 \cdot 001$ ) compared with the Lep group (Fig. 4B).

\section{Western blot of the hypothalamic and thyroidal leptin receptor}

The levels of hypothalamic (Fig. 5) and thyroidal (Fig. 6) $\mathrm{OB}-\mathrm{Rb}$ receptor expression were respectively $47 \%(P<0 \cdot 01)$ and $36 \%(P<0 \cdot 05)$ lower in the Lep group and restored to normal levels after cold exposure in LepC group. Quantity controls were obtained by performing parallel western blot of the housekeeping actin.

\section{Discussion}

We determined for the first time, the effect of the cold exposure on the body weight, thyroid function, serum leptin, and $\mathrm{OB}-\mathrm{Rb}$ protein content on hypothalamus and thyroid gland of 30-day-old rats that were leptin treated during the first 10 days of life.

The data on lower body weight during lactation in the Lep group reinforces our previous finding (Oliviera Cravo et al. 2002, Toste et al. 2006b). However, after weaning, these animals recovered the body weight and had the same body weight of the control group until day 30 of life. So, the body weight during lactation was decreased by this leptin treatment. 
A

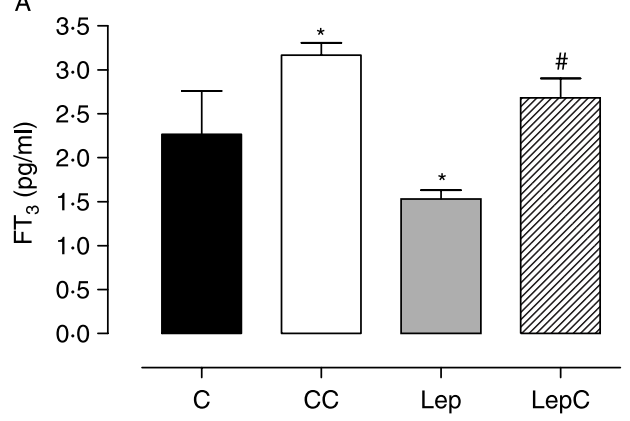

B

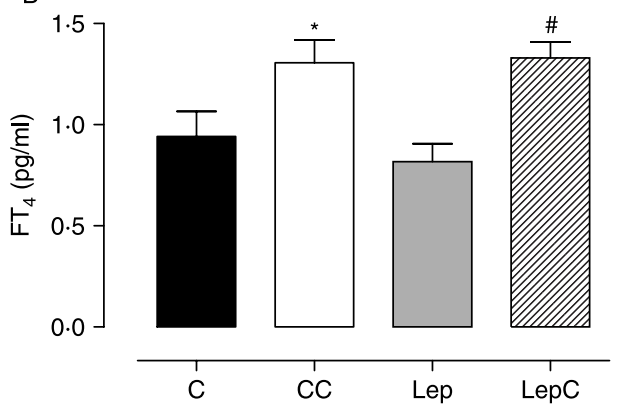

C

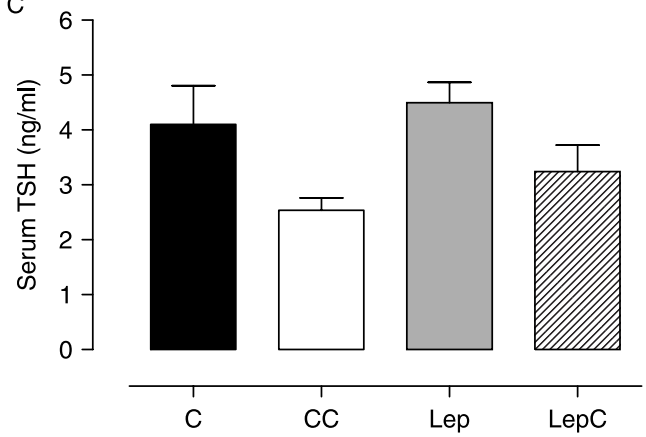

Figure 3 Serum concentrations of $(A)$ free $T_{4},(B)$ free $T_{3}$, and $(C)$ $\mathrm{TSH}$ of animals treated with saline and kept at $25^{\circ} \mathrm{C}$ when 30 days old (C group, black bar), treated with saline and exposed to $8{ }^{\circ} \mathrm{C}$ for $12 \mathrm{~h}$ (CC group, white bar), treated with leptin on the first 10 days of lactation and kept at $25^{\circ} \mathrm{C}$ when 30 days old (Lep group, gray bar), and treated with leptin on the first 10 days of lactation and exposed to $8{ }^{\circ} \mathrm{C}$ for $12 \mathrm{~h}$ when 30 days old (LepC group, hatched bars).

Values are given as the mean \pm s.E.M. of eight animals per group. $\left.{ }^{*}\right)$ Significant differences between Lep and CC groups and C, (\#) between LepC and Lep. The level of significance was set at $P<0 \cdot 05$.

Control cold-exposed rats had lower food intake and consequently lower body weight. In fact, cold stress may play an important role on these effects, since a more prolonged cold exposition is associated with higher food intake (Bing et al. 1998, Gasparetti et al. 2003, Torsoni et al. 2003). The Lep group when cold exposed had a lower decrease in food intake, compared with the cold-exposed controls, and did not have body weight changes. The fact that the LepC group ate relatively more than $\mathrm{CC}$ group could be explained by the fact that only in the LepC group leptin levels fell after cold
A

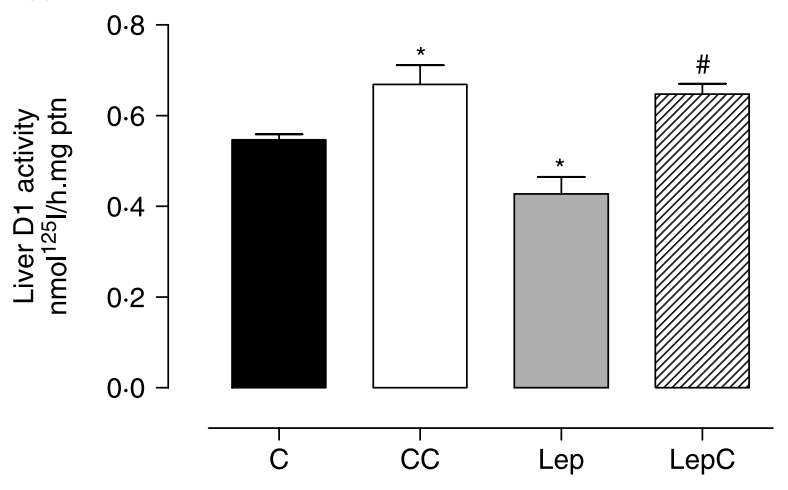

B

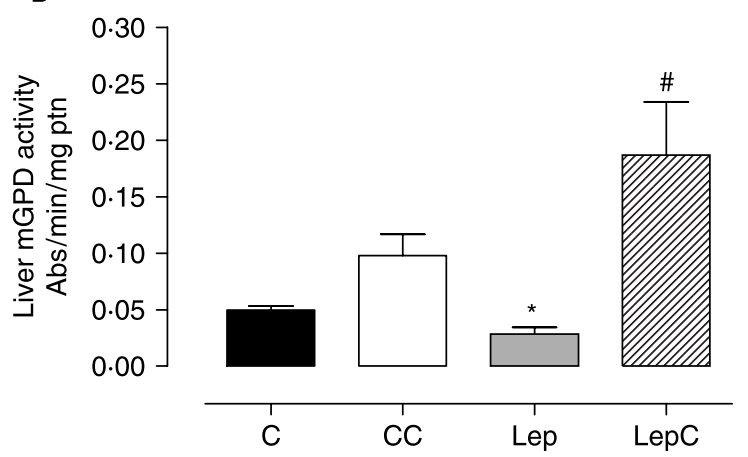

Figure 4 (a) Liver D1 and (b) mGPD activities of animals treated with saline and kept at $25^{\circ} \mathrm{C}$ when 3 days old (C group, black bar), treated with saline and exposed to $8{ }^{\circ} \mathrm{C}$ for $12 \mathrm{~h}$ (CC group, white bar), treated with leptin on the first 10 days of lactation and kept at $25^{\circ} \mathrm{C}$ when 30 days old (Lep group, gray bar), and treated with leptin on the first 10 days of lactation and exposed to $8{ }^{\circ} \mathrm{C}$ for $12 \mathrm{~h}$ when 30 days old (LepC group, hatched bars). Values are given as the mean \pm S.E.M. of eight animals per group. (*) Significant differences between Lep and CC groups and C, $(\#)$ between LepC and Lep. The level of significance was set at $P<0 \cdot 05$.

exposure. Since leptin suppresses food intake, less leptin could counterbalance the anorectic effect of cold stress.

In respect to the programming effects of leptin on body weight regulation, our data disagree with some reports (Stocker et al. 2004, Picò et al. 2007). It is possible that these differences occur mainly because of the amount, period, and route ofleptin administered. In the study by Stocker et al. (2004), the administration of leptin from day 14 of pregnancy and throughout lactation to rats fed on a low-protein diet reduces the susceptibility of a high-fat diet to induce higher weight gain. Contrary to our study, Stocker et al. (2004) report the effect leptin given to the mother from the third part of gestation did not study the effect of leptin treatment in mothers fed a standard chow diet. The model of Stocker et al. (2004) is a more complex one, which involves several variables such as: two different periods of development (pregnancy and lactation), undernutrition during the treatment, and a higher fat diet after weaning. Our model is a more physiological one, since the animals received a normal diet during the study period. In other 
A
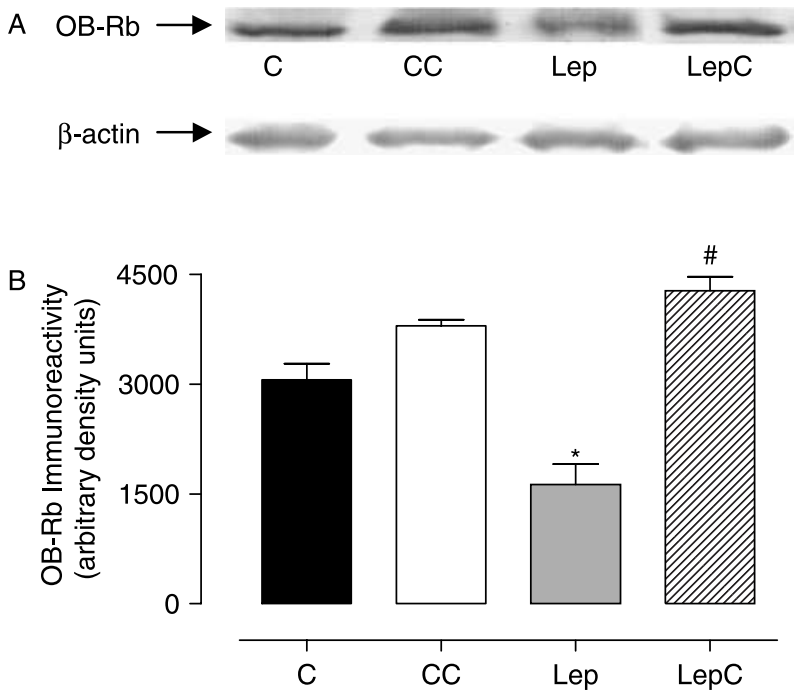

Figure 5 (A) Western blot analysis and (B) densitometric analysis of the immunoreactive bands of the hypothalamic OB-Rb of animals treated with saline and kept at $25^{\circ} \mathrm{C}$ (C group, black bar) when 30 days old, treated with saline and exposed to $8{ }^{\circ} \mathrm{C}$ for $12 \mathrm{~h}$ (CC group, white bar), treated with leptin on the first 10 days of lactation and kept at $25^{\circ} \mathrm{C}$ when 30 days old (Lep group, gray bar), and treated with leptin on the first 10 days of lactation and exposed to $8{ }^{\circ} \mathrm{C}$ for $12 \mathrm{~h}$ when 30 days old (LepC group, hatched bars). Also shown is the western blot analysis of $\beta$-actin. Values are given as the mean \pm S.E.M. of five animals per group. $\left.{ }^{*}\right)$ Significant differences between Lep and CC groups and C, (\#) between LepC and Lep. The level of significance was set at $P<0 \cdot 05$.

previous reports of our group (Lins et al. 2005, Passos et al. 2007), we injected leptin into the mother for a shorter period ( 3 days at the end of lactation) and observed that the offspring were programmed for higher body weight and higher food intake, when they were 180 days old. In the study of Picò et al. (2007), the daily oral dose of leptin (fivefold the leptin milk concentration) was given to suckling male rats during lactation. After weaning, the pups were fed with a normal fat or a high-fat diet. Leptin-treated animals had, in adulthood, lower body weight, fat content, food intake, and hypoleptinemia. However, with this amount of leptin, they did not observe body weight changes during lactation. We showed previously that leptin injection reduces pups body weight, even when leptin was injected in the mother (Oliviera Cravo et al. 2002, Lins et al. 2005, Toste et al. 2006b).

At 30 days of age, leptin-programmed rats had lower serum $\mathrm{T}_{3}$, hepatic mGPD, and D1 activities. Nevertheless, those animals showed a higher response of $\mathrm{TH}$ when cold exposed compared with the controls, with a consequent higher increase in $\mathrm{mGPD}$ and hepatic D1 activities.

One week after weaning, neonatal leptin-treated rats presented a persistent hyperleptinemia, resistance to the anoretic effect of this hormone (Toste et al. 2006b), and a lower expression of hypothalamic and thyroidal OB-Rb receptors. Some nutritional or hormonal mechanism might link the anorectic effect of leptin on the first 10 days of
A

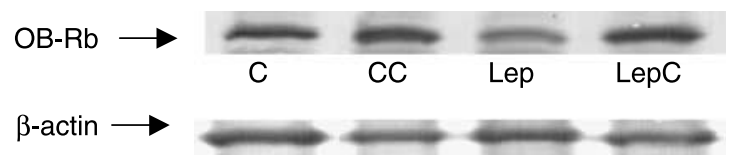

B

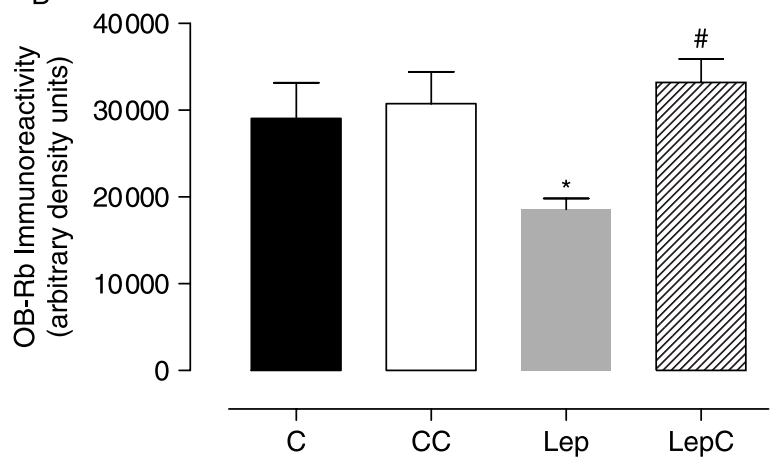

Figure 6 (A) Western blot analysis and (B) densitometric analysis of the immunoreactive bands of the thyroidal OB-Rb of animals treated with saline and kept at $25^{\circ} \mathrm{C}$ when 30 days old (C group, black bar), treated with saline and exposed to $8{ }^{\circ} \mathrm{C}$ for $12 \mathrm{~h}$ (CC group, white bar), treated with leptin on the first 10 days of lactation and kept at $25{ }^{\circ} \mathrm{C}$ when 30 days old (Lep group, gray bar), and treated with leptin on the first 10 days of lactation and exposed to $8^{\circ} \mathrm{C}$ for $12 \mathrm{~h}$ when 30 days old (LepC group, hatched bars). Also shown is the western blot analysis of $\beta$-actin. Values are given as the mean \pm S.E.M. of five animals per group. $\left({ }^{*}\right)$ Significant differences between Lep and CC groups and C, (\#) between LepC and Lep. The level of significance was set at $P<0 \cdot 05$.

lactation with an increment of leptin after weaning. Maybe those animals, which had a decrease in food intake in those early days of life, when they were given chow ad libitum, after weaning, increases their intake and they quickly gain more adipose tissue, producing more leptin. Those with hyperleptinemia, according to the known phenomena of down-regulation, can be responsible for the lower expression of $\mathrm{OB}-\mathrm{Rb}$ receptors both at the thyroid and hypothalamus. The stimulatory effect of leptin on the thyroid function is well known, through its effects at the hypothalamic level, increasing $\mathrm{TRH}$, or its direct effects on the thyroid gland (Legradi et al. 1997, Nowak et al. 2002, Ortiga-Carvalho et al. 2002). In the present situation, it is possible that downregulated receptors cause a resistance to the leptin effect both at hypothalamic and thyroidal levels, leading to a thyroid hypofunction. Consequent to the decrease on the thyroid function, those animals had decreased activity of liver D1 and mGPD enzymes that are thyroid hormone dependent.

Cold exposure is associated with rapid activation of the hypothalamus-pituitary-thyroid axis (Hefco et al. 1975, Joseph-Bravo et al. 1998), peripheral conversion of $\mathrm{T}_{4}$ into $\mathrm{T}_{3}$ (Pazos-Moura et al. 1991, Reed et al. 1994, Lisboa et al. 2003), and low levels of circulating leptin (Hardie et al. 1996, Bing et al. 1998). Increase in catecholamine secretion can play 
a role on these changes. Catecholamine has a stimulatory effect on thyroidal $\mathrm{T}_{3}$ production (Shimura et al. 1990) as well as D1 (Aceves \& Rojas-Huidobro 2001) and D2 activities (Silva \& Larsen 1983). Also, it mediates the cold-induced suppression of leptin expression (Trayhurn et al. 1995). Norepinephrine deficiency is also associated with a resistance in leptin action on brown and adipose tissues (Commins et al. 1999), suggesting that norepinephrine stimulates OB-Rb expression on these tissues. In fact, we showed recently that those programmed animals presented higher catecholamine adrenal content and higher basal and caffeine-stimulated in vitro secretion (Trevenzoli et al. 2007). Thus, in this present study, catecholamine may have a higher increase when those leptin-programmed animals are cold exposed, increasing the $\mathrm{OB}-\mathrm{Rb}$ protein content at the hypothalamus and thyroid gland, and this factor could contribute to the higher TH cold responses.

Higher TH response in leptin-programmed cold-exposed animals is associated with a higher liver mGPD and D1 activities. This effect is more marked over mGPD. The animals may have a better adaptation to cold environment than controls when mGPD have a thermogenic effect (Dos Santos et al. 2003).

Leptin increases D1 activity in liver (Lisboa et al. 2003) and D2 activity in BAT (Cettour-Rose et al. 2002), stimulating $\mathrm{T}_{3}$ production. Thus, in leptin-programmed animals exposed to cold, the higher serum $T_{3}$ seems to be, at least in part, due to the peripheral conversion of $T_{4}$ into $T_{3}$. In this study, leptinprogrammed cold-exposed animals showed lower serum leptin concentration, suggesting that the main source of $T_{3}$ could be the thyroidal supply. We cannot discard that the same phenomena observed for thyroidal OB-Rb receptors, with a rapid recovery of its lower levels observed at room temperature, could be happening with the hepatic leptin receptors.

In conclusion, the main finding of this paper is to show that the physiological changes observed in leptin-treated neonatal animals, 1 week after weaning, can be corrected by cold exposure, both at the leptin and thyroid functional level, with probable consequences for cold adaptation and body weight regulation of those programmed animals.

\section{Acknowledgements}

This research was supported by the National Council for Scientific and Technological Development (Conselho Nacional de Desenvolvimento Científico e Tecnológico; CNPq), Coordination for the Enhancement of Higher Education Personnel (Coordenação de Aperfeiçoamento de Pessoal de Nível Superior; CAPES), and the State of Rio de Janeiro Carlos Chagas Filho Research Foundation (Fundação de Amparo à Pesquisa do Rio de Janeiro; FAPERJ). All authors are grateful to Ms Lauciene Andrade and Mr Carlos Roberto for their technical assistance. The authors declare that there is no conflict of interest that would prejudice the impartiality of this scientific work.

\section{References}

Aceves C \& Rojas-Huidobro R 2001 Effect of suckling and adrenergic stimulation on peripheral deiodination in lactating rats: differential expression of type 1 deiodinase mRNA forms. Journal of Endocrinology 171 533-540.

Armitage JA, Khan IY, Taylor PD, Nathanielsz PW \& Poston L 2004 Developmental programming of the metabolic syndrome by maternal nutritional imbalance: how strong is the evidence from experimental models in mammals? Journal of Physiology 561 355-377.

Bayne K 1996 Revised guide for the care and use of laboratory animals available. American Physiological Society and Physiology 39 208-211.

Bernal J, Coleoni AH \& DeGroot LJ 1978 Triiodothyronine stimulation of nuclear protein synthesis. Endocrinology 102 452-459.

Bianco AC \& Silva JE 1987 Optimal response of key enzymes and uncoupling protein to cold in BAT depends on local $\mathrm{T}_{3}$ generation. American Journal of Physiology 253 E255-E263.

Bing C, Frankish HM, Pickavance L, Wang Q, Hopkins DF, Stock MJ \& Williams G 1998 Hyperphagia in cold-exposed rats is accompanied by decreased plasma leptin but unchanged hypothalamic NPY. American Journal of Physiololgy. Regulatory, Integrative and Comparative Physiology 274 R62-R68.

Bradford MM 1976 A rapid and sensitive method for the quantification of microgram quantities of protein utilizing the principle of protein-dye binding. Analytical Biochemistry 72 248-254.

Carvalho SD, Kimura ET, Bianco AC \& Silva JE 1991 Central role of brown adipose tissues thyroxine 5-deiodinase on thyroid hormone-dependent thermogenic response to cold. Endocrinology 128 2149-2159.

Cettour-Rose P, Burger AG, Meier CA, Visser TJ \& Rohner-Jeanrenaud F 2002 Central stimulatory effect of leptin on $\mathrm{T}_{3}$ production is mediated by brown adipose tissue type 2 deiodinase. American Journal of Physiology. Endocrinology and Metabolism 283 E980-E987.

Commins SP, Marsh DJ, Thomas SA, Watson PM, Padgett MA, Palmiter R \& Gettys TW 1999 Norepinephrine is required for leptin effects on gene expression in brown and white adipose tissue. Endocrinology 140 4772-4778.

Dutra SCP, Passos MCF, Lisboa PC, Santos RS, Cabanelas AP, Pazos-Moura CC \& Moura EG 2003 Liver deiodinase activity is increased in adult rats whose mothers were submitted to malnutrition during lactation. Hormone Metabolic Research 35 268-270.

Fishbeck KL \& Rasmussen KM 1987 Effect of repeated cycles on maternal nutritional status, lactational performance and litter growth in ad libitum fed and chronically food-restricted rats. Journal of Nutrition 117 1967-1975.

Gasparetti AL, Souza CT, Pereira-da-Silva M, Oliveira RLGS, Saad MJA, Carneiro E \& Velloso LA 2003 Cold exposure induces tissue-specific modulation of the insulin-signalling pathway in Rattus norvegicus. Journal of Physiology 552 149-162.

Gong DW, He Y, Karas M \& Reitman M 1997 Uncoupling protein-3 is a mediador of thermogenesis regulated by thyroid hormone, beta 3-adrenergic agonists, and leptin. Journal of Biological Chemistry 272 24129-24132.

Hardie LJ, Rayner DV, Holmes S \& Trayhurn P 1996 Circulating leptin levels are modulated by fasting, cold exposure and insulin administration in lean but not Zucker $(\mathrm{fa} / \mathrm{fa})$ rats as measured by ELISA. Biochemical and Biophysical Research Communications 223 660-665.

Hausberg M, Morgan DA, Mitchell JE, Sivitiz WI, Mark AL \& Hynes WG 2002 Leptin potentiates thermogenic sympathetic responses to hypothermia: a receptor-mediated effect. Diabetes 51 2434-2440.

Hefco E, Krulich P, Illner P \& Larsen PR 1975 Effect of acute exposure to cold on the activity of the hypothalamic-pituitary-thyroid system. Endocrinology 97 1185-1195.

Joseph-Bravo P, Uribe RM, Vargas MA, Peres-Martinez L, Zoeller T \& Charli JL 1998 Multifatorial modulation of TRH metabolism. Cellular and Molecular Neurobiology 18 231-247. 
Lee YP \& Lardy HÁ 1965 Influence of thyroid hormones on L-GPD and other dehydrogenases in various organs of the rat. Journal of Biological Chemistry 240 1427-1436.

Legradi G, Emerson CH, Ahima RS, Flier JS \& Lechan RM 1997 Leptin prevents fasting-induced suppression of prothyrotropin-releasing hormone messenger ribonucleic acid in neurons of the hypothalamic paraventricular nucleus. Endocrinology 138 2569-2576.

Lins MC, de Moura EG, Lisboa PC, Bonomo IT \& Passos MC 2005 Effects of maternal leptin treatment during lactation on the body weight and leptin resistance of adult offspring. Regulatory Peptides 127 197-202.

Lisboa PC, Oliveira KJ, Cabanelas A, Ortiga-Carvalho TM \& Pazos-Moura CC 2003 Acute cold exposure, leptin, and somatostatin analog (octreotide) modulate thyroid 5'-deiodinase activity. American Journal of Physiology. Endocrinology and Metabolism 284 E1172-E1176.

Moura EG \& Passos MCF 2005 Neonatal programming of body weight regulation and energetic metabolism. Bioscience Reports 25 251-269.

Nillni EA, Vaslet C, Harris M, Hollenberg A, Bjorbaek C \& Flier JS 2000 Leptin regulates prothyritropin-releasing hormone biosynthesis. Journal of Biological Chemistry 275 36124-36133.

Nowak KW, Kaczmarek P, Mackowiak P, Ziolkowska A, Albertin G, Ginda WJ, Trejter M, Nussdorfer GG \& Malendowicz LK 2002 Rat thyroid gland expresses the long form of leptin receptors, and leptin stimulates the function of the gland in euthyroid non-fasted animals. International Journal of Molecular Medicine 9 31-34.

Oliviera Cravo C, Teixeira CV, Passos MC, Dutra SC, de Moura EG \& Ramos C 2002 Leptin treatment during the neonatal period is associated with higher food intake and adult body weight in rats. Hormone Metabolic Research 34 400-405.

Ortiga-Carvalho TM, Oliveira KJ, Soares BA \& Pazos-Moura CC 2002 Leptin role in the regulation of thyrotropin secretion in fed state - in vivo and in vitro studies. Journal of Endocrinology 174 121-125.

Passos MCF, Ramos CF \& Moura EG 2000 Short and long term effects of malnutrition in rats during lactation on the body weight of offspring. Nutrition Research 20 1603-1612.

Passos MCF, Ramos CF, Dutra SCP, Mouço T \& Moura EG 2002 Long-term effects of malnutrition during lactation on the thyroid function of offspring. Hormone Metabolic Research 34 40-43.

Passos MCF, Lins MC, Lisboa PC, Bonomo I, Toste FP \& Moura EG 2007 Maternal leptin treatment during lactation programs the thyroid function of adult rats. Life Sciences 80 1754-1758.

Pazos-Moura CC, Moura EG, Dorris ML, Rehnmark S, Melendez L, Silva JE \& Taurog A 1991 Effect of iodine deficiency and cold exposure on thyroxine $5^{\prime}$-deiodinase activity in various rat tissues. American Journal of Physiology. Endocrinology and Metabolism 260 E175-E182.

Picó C, Oliver P, Sanchez J, Miralles O, Caimari A, Priego T \& Palou A 2007 The intake of physiological doses of leptin during lactation in rats prevents obesity in later life. International Journal of Obesity 13 1-11.

Puerta M, Abelenda M, Rocha M \& Trayhurn P 2002 Effect of acute cold exposure on the expression of the adiponectin, resistin and leptin genes in rat white and brown adipose tissues. Hormone Metabolic Research 34 629-634.

Recupero AR, Coleoni AH, Cherubini O \& Oviedo A 1983 Selective alterations in hepatic nuclear $\mathrm{T}_{3}$-receptors and enzyme responses by glucocorticoid deficit or excess. Acta Endocrinologica 104 485-489.

Reed HL, Quesada M, Hesslink RL, D'Alesandro MM, Hays MT, Christopherson RJ, Turner BV \& Young BA 1994 Changes in serum triiodothyronine kinetics and hepatic type I 5 -deiodinase activity of coldexposed swine. American Journal of Physiology. Endocrinology and Metabolism 266 E786-E795
Dos Santos RA, Alfada A, Eto K, Kadowaki T \& Silva JE 2003 Evidence for a compensad thermogenic defect in transgenic mice, lacking the mitocondrial glycerol 3-phosphate dehydrogenase gene. Endocrinology 144 5469-5479.

Silva JE 1995 Thyroid hormone control of thermogenesis and energy balance. Thyroid 5 481-492.

Silva JE \& Larsen PR 1983 Adrenergic activation of triiodothyronine production in brown adipose tissue. Nature 305 712-713.

Shimura H, Endo T \& Onaya T 1990 Thyrotrophin increases the alpha 1badrenergic receptors in rat thyroid gland in vivo. Journal of Endocrinology 126 $317-322$.

Stocker C, O'Dowd J, Morton NM, Wargent E, Senitt MV, Hislop D, Glund S, Seckl JR, Arch JRS \& Cawthorne MA 2004 Modulation of susceptibility to weight gain and insulin resistance in low birthweight rats by treatment of their mothers with leptin during pregnancy and lactation. International Journal of Obesity 28 129-136.

Tartaglia LA 1997 The leptin receptor. Journal of Biological Chemistry 272 6093-6096.

Teixeira C, Passos MC, Ramos CD, Dutra SCP \& Moura EG 2002 Leptin serum concentration, food intake and body weight in rats whose mothers were exposed to malnutrition during lactation. Journal of Nutritional Biochemistry 13493.

Torsoni MA, Cavalheira JB, Pereira-da-Silva M, Carvalho-Filho MA, Saad MJA \& Velloso LA 2003 Molecular and functional resistance to insulin in hypothalamus of rats exposed to cold. American Journal of Physiology. Endocrinology and Metabolism 285 E216-E223.

Toste FP, Alves SB, Dutra SCP, Bonomo IT, Lisboa PC, Moura EG \& Passos MCF 2006a Temporal evaluation of the thyroid function of rats programmed by leptin treatment on the neonatal period. Hormone Metabolic Research 38 827-831.

Toste FP, de Moura EG, Lisboa PC, Fagundes AT, de Oliveira E \& Passos MC $2006 b$ Neonatal leptin treatment programmes leptin hypothalamic resistance and intermediary metabolic parameters in adult rats. British Journal of Nutrition 95 830-837.

Trayhurn P, Duncan JS \& Rayner DV 1995 Acute cold-induced suppression of ob (obese) gene expression in white adipose tissue of mice: mediation by the sympathetic system. Biochemical Journal 311 729-733.

Trevenzoli IH, Valle MM, Machado FB, Garcia RM, Passos MC, Lisboa PC \& Moura EG 2007 Neonatal hyperleptinemia programmes adrenal medullary function in adult rats: effects on cardiovascular parameters. Journal of Physiology $\mathbf{5 8 0}$ 629-637.

Ukropec J, Anunciado RV, Ravussin Y \& Kozak LP 2006 Leptin is required for uncoupling protein-1-independent thermogenesis during cold stress. Endocrinology 147 2468-2480.

Vicente LL, Moura EG, Lisboa PC, Costa AMA, Amadeu T, Mandarim de Lacerda CA \& Passos MCF 2004 Malnutrition during lactation is associated with higher expression of leptin receptor in pituitary of the adult rats. Nutrition 20 924-928.

\section{Received in final form 17 August 2007 \\ Accepted 28 August 2007 \\ Made available online as an Accepted Preprint 28 August 2007}

